\title{
MICRO-MORPHOLOGY OF THE SNOW SURFACE AT THE QUELCGAYA ICE CAP, PERU
}

\author{
By Stefan Hastenrath \\ (Department of Meteorology, University of Wisconsin, Madison, Wisconsin 53706, U.S.A.) \\ and Bruge KocI \\ (Polar Ice Coring Office, University of Nebraska, Lincoln, Nebraska 68588, U.S.A.)
}

\begin{abstract}
During the June-July 1979 expedition a large variety of micro-forms was observed at the surface of the Quelccaya ice cap, their altitudinal distribution being primarily controlled by the heat budget. At 5 200-5 $300 \mathrm{~m}$ penitentes are best developed, with azimuth orientation and inclination of features conforming to the insolation geometry around local noon. At a westward-facing slope in $5360-5380 \mathrm{~m}$ a set of penitentes striking parallel to the contours is superimposed on the pattern dominating at the lower elevations. The ablation forms of penitentes give way to various deposition features above a transition zone around $5400 \mathrm{~m}$ in broad agreement with the larger net all-wave radiation and greater importance of melting at lower elevations. The succession of forms with an upward change from surface-parallel plates to elaborate dendritic forms appears to be controlled by the temperature conditions. The conspicuous development of forms encountered during the 1979 expedition appears characteristic of prolonged absence of fresh snow-fall subsequent to a season with abundant precipitation.
\end{abstract}

RÉsumé. Micro-morphologie de la surface de la neige sur la calotte glaciaire de Quelccaya au Pérou. Au cours de l'expédition de juin-juillet 1979, on a observé à la surface de la calotte glaciaire de Quelccaya, une grande variété de micro-formes dont la distribution altitudinale était surtout influencée par le bilan thermique. A 5 200-5 $300 \mathrm{~m}$, ce sont les pénitents qui sont le mieux développés avec une orientation azimutale et une inclinaison des formes conforme à la géométrie de l'insolation locale à midi. Sur une pente exposée à l'Ouest vers $5360-5380 \mathrm{~m}$, un lot de pénitents parallèles aux courbes de niveau se surimpose sur la disposition qui domine aux altitudes inférieures. Les formes d'ablation des pénitents donnent lieu à différents types de disposition au-dessus d'une zone de transition autour de $5400 \mathrm{~m}$, ce qui est en accord avec le plus fort bilan radiatif global et la plus grande importance de la fusion aux altitudes inférieures. La succession des formes avec un changement vers le haut depuis celles d'assiettes parallèles à la surface jusqu'à des formes dendritiques élaborées, semble être sous le contrôle des conditions de température. Le considérable développement des formes rencontrées durant l'expédition de I979 apparaît caractéristique d'une absence prolongée de chutes de neige fraîche succédant à une saison avec abondantes précipitations.

Zusammenfassung. Mikro-Morphologie der Schneedecke auf der Quelccaya-Eiskappe, Perú. Während der Expedition im Juni-Juli r 979 waren auf Quelccaya eine Fülle von Mikro-Oberflächenformen zu beobachten, deren Vertikalverteilung vornehmlich aus dem Wärmehaushalt verständlich ist. Penitentes sind um 5 200-5 $300 \mathrm{~m}$ am besten entwickelt, wobei Azimut-Orientierung und Einfallen der Penitentes-Blätter im wesentlichen der Einstrahlungs-Geometrie um Mittag entspricht. Auf einem nach Westen gerichteten Hang in 5 360-5 $380 \mathrm{~m}$ Höhe sind Penitentes-Formen parallel zu den Höhenlinien angelegt und kreuzen das für die niederen Lagen beschriebene Muster. Die Ablationsformen der Penitentes verschwinden in einer Übergangszone um $5400 \mathrm{~m}$, oberhalb derer verschiedenen Ablagerungsformen vorherrschen. Dieser Übergang stimmt in grossen Zügen mit dem Wechsel von positiver Strahlungsbilanz in den unteren zu negativen Werten in den grösseren Höhenlagen überein. Die Abfolge der Kristallformen, mit einem höhenwärtigen Wandel von Plättchen zu Nadeln, und schliesslich zu Dendritenformen, scheint durch die Temperaturverhältnisse bedingt. Die auffällige Entwicklung der Oberflächen-Kleinformen im Jahre I 979 scheint charakteristisch für das lange Fehlen von Neuschnee, das auf eine Jahreszeit mit reichlichem Niederschlag folgte.

\section{INTRODUGtion}

A multi-annual field project is being conducted on the Quelccaya ice cap in the eastern Andes of Peru, geared at the retrieval of ice cores for climate reconstruction. The study of the recent climate and heat and mass budget is an important component of this field effort, in terms of providing a modern background for paleoclimatic interpretations. The Quelccaya ice cap is located at around lat. $14^{\circ} \mathrm{S}$., has an area of about $54 \mathrm{~km}^{2}$ and a summit elevation of $5650 \mathrm{~m}$ (Fig. I). Details of environmental setting and of earlier project results have been described in various publications (Hastenrath, 1978; Thompson and others, 1979). The 
present paper discusses some field observations during the June-July I979 expedition conducted by the Institute of Polar Studies of Ohio State University with participation by the Department of Meteorology of the University of Wisconsin, the Polar Ice Coring Office at the University of Nebraska, and the Instituto de Geología y Minería of Peru.

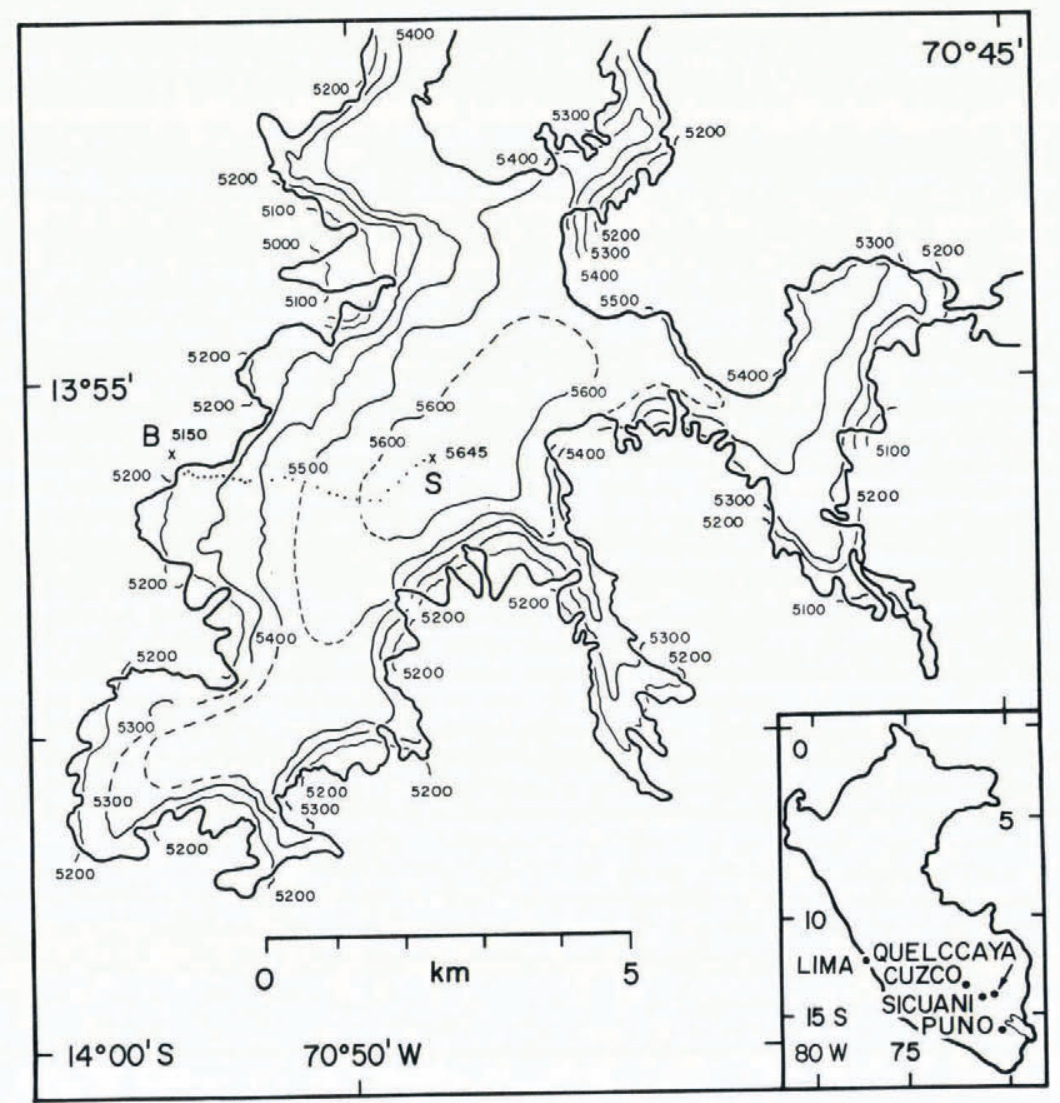

Fig. I. Orientation map. Ice rim is indicated by heavy solid, and travel route by dotted line. $B$ and $S$ denote base camp and summit, respectively. Elevations in meters.

\section{Observations}

The various project tasks in the peak region required daily trips between the camp established near the ice rim at $5150 \mathrm{~m}$ and the summit at $565^{\circ} \mathrm{m}$. These traverses provided ample opportunity to observe the change of snow surface characteristics with elevation. Altitudinal variations in surface morphology were found to be rather more pronounced than during the earlier expeditions. Characteristic features are described in the following.

At the lowest elevations, between the ice rim near $5200 \mathrm{~m}$ and about $5300 \mathrm{~m}$, penitente forms were found in best development (Fig. 2). Penitentes consisted of sheets or boards of snow arranged with a regular west-east striking and a dip of about $50^{\circ}$ towards the north. This compares well with the noon zenith angle of the sun for the winter solstice at $14^{\circ} \mathrm{S}$., namely about $3^{\circ}$, as discussed in the literature (Troll, I942, p. 33-36; Hofmann, I964; Kraus, I966).

Above $5300 \mathrm{~m}$ the penitentes are smaller and the pattern becomes irregular. Between 5360 and $5380 \mathrm{~m}$ on a wide westward-facing slope, another penitente pattern with a broadly 
contour-parallel strike, larger zenith angle, and sheets pointing towards the west, appears superimposed on the pattern described above for the lower elevations (Figs 3-4). Proceeding upward the pattern parallel to the contours becomes the more conspicuous one.

At elevations around $5420 \mathrm{~m}$ the ablation forms of penitentes vanish, and give way to the appearance of large essentially surface-parallel plate-shaped ice crystals, with typical diameters of 5-10 mm (Fig. 5). Proceeding towards higher elevations, the crystal plates occupy an increasing fraction of the total surface; large plates accounting for about half of the area at $5600 \mathrm{~m}$.

Above $5600 \mathrm{~m}$, plates are replaced by column-shaped crystals (Fig. 6), over a comparatively small elevation interval. Needle-shaped crystals seem to be less common. The highest part of the summit plateau upward of $5630 \mathrm{~m}$ is dominated by elaborate dendritic crystal forms (Fig. 7). Elements tend to be oriented towards west of north, in accordance with the seasonally-prevailing wind direction.

Observations during this prolonged period without snow-fall thus show a pronounced altitudinal variation of surface morphology, ranging from various ablation forms in the lower, to deposition phenomena in the upper part of the ice cap. As a background for the understanding of the observed altitudinal zonation of surface features, some aspects of the heat budget will be reviewed in the following section.

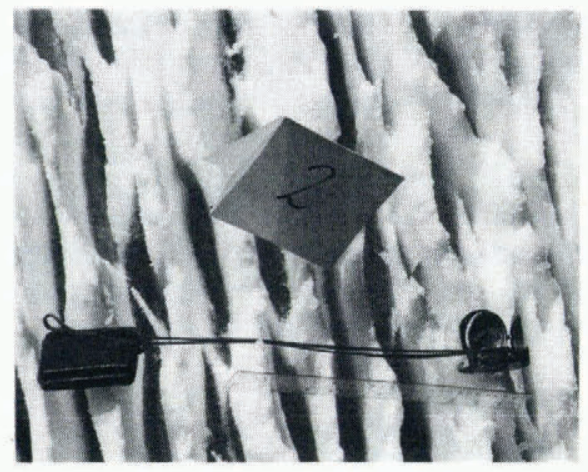

Fig. 2. Penitente field at $5200 \mathrm{~m}$. Compass and string indicate north direction to left. Plastic ruler as scale.

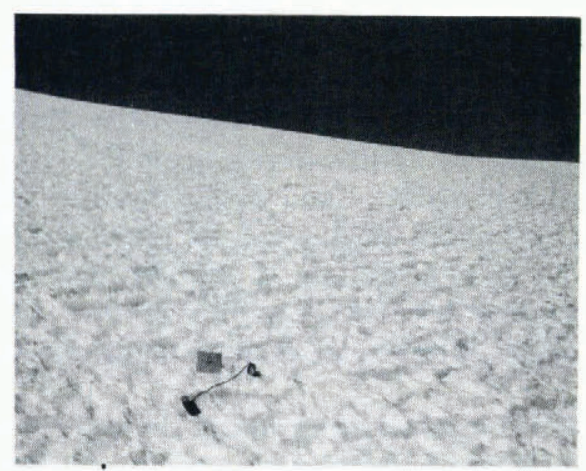

Fig. 4. Field of cross-patterned penitentes at $5370 \mathrm{~m}$. Compass, string, and plastic ruler serve same purpose as in Figure 3.

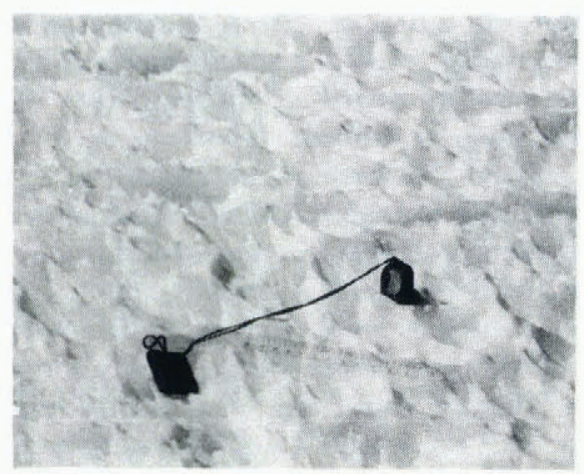

Fig. 3. Cross-pattern of penitentes at $5370 \mathrm{~m}$. Compass and string indicate north direction to left, and plastic ruler is placed approximately parallel to terrain contours.

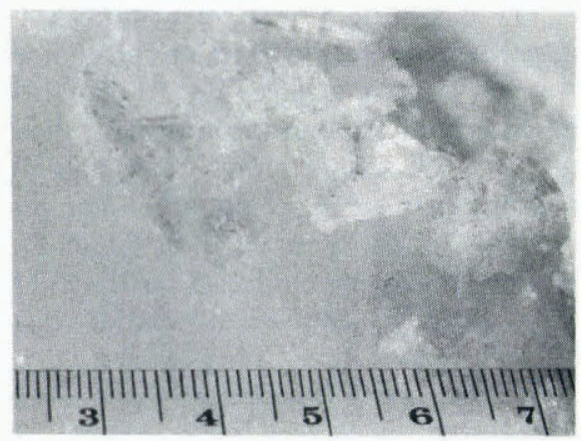

Fig. 5. Plate-shaped ice crystals at $5470 \mathrm{~m}$. Plastic ruler as scale. 


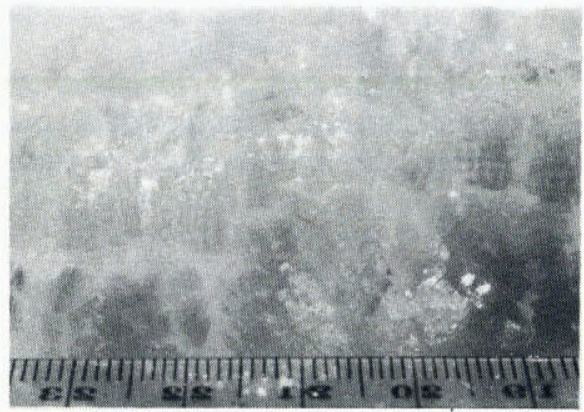

Fig. 6. Column shaped ice crystals at $5640 \mathrm{~m}$. Plastic ruler as scale.

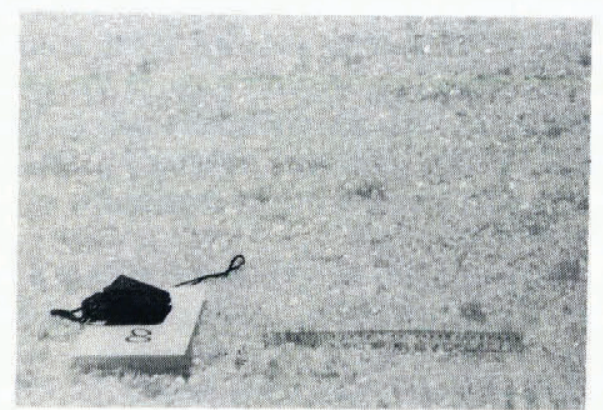

Fig. 7. Dendritic ice crystals at $5650 \mathrm{~m}$. Plastic ruler and compass as scale.

\section{Heat budget}

The heat budget equation for the surface can in approximate form be written

$$
(S W \downarrow)-(S W \uparrow)+(L W \uparrow \downarrow)=Q_{\mathrm{e}}+Q_{\mathrm{m}}+Q_{\mathrm{s}}+Q_{\mathrm{t}} .
$$

Here the left-hand terms denote downward and upward directed short-wave and net longwave radiation. The first three right-hand terms signify latent heat flux, heat used for melting, and sensible heat flux, respectively. The last right-hand term combines storage and vertical heat fluxes within the ice.

Based on measurements during the 1976 and 1977 expeditions, methods have been developed to calculate surface net all-wave radiation, that is the left side of Equation ( $\mathrm{I}$ ), as a function of cloudiness and albedo; and representative albedo values have been tabulated for elevation bands (Hastenrath, 1978). These data will be used here although somewhat smaller albedo values were measured after a prolonged period without snow-fall in early July 1979. A qualitative discussion appears appropriate here.

The first and third terms on the left-hand side of Equation (I) are rather uniform all over the ice cap, while the second left-hand term is a function of albedo and hence elevation. Accordingly, the net all-wave radiation decreases from appreciable positive values near the ice rim to figures near zero on the summit plateau. The net all-wave radiation in turn must approximately equal the first two right-hand terms of Equation (I), inasmuch as the last two terms on the right are small. The energy available for ablation thus decreases strongly with elevation.

The dependence of the ablation of ice mass on elevation is further accentuated by the temperature conditions, in that the latent heats of evaporation and melting differ by almost an order of magnitude. The thermal regime at the Quelccaya summit in southern winter is characterized by daily maximum, mean, and minimum air temperatures around $-3,-8$, and $-\mathrm{I}^{\circ} \mathrm{C}$, respectively. Accordingly, melting at the surface, and hence more sizeable ablation, can be expected at elevations from around $5400 \mathrm{~m}$ downward, in particular. By contrast, on the vast summit plateau, where net all-wave radiation is anyhow near zero, ablation would be confined to the energetically expensive evaporation. This state of affairs is confirmed by concurrent radiation, lysimeter, and profile measurements during the 1976 and 1977 expeditions (Hastenrath, I978).

In relation to the penitente phenomenon, the radiation geometry around the time of day with largest insolation is of interest. For an approximately horizontal surface the corresponding solar azimuth is north and the zenith angle equal to declination plus latitude. Conditions are more complicated for slopes. 


\section{Conclusions}

The prominent characteristics in the altitudinal distribution of surface features will be examined in terms of the heat budget. This seems appropriate because the surface has remained unaffected by fresh snow-fall for a prolonged period. The following aspects are of interest in particular:

(i) The transition from the ablation form of penitentes to the dominance of variously shaped ice crystals, which represent deposition features, takes place around $5400 \mathrm{~m}$, in broad agreement with the larger net all-wave radiation and greater importance of melting at lower elevations.

(ii) Penitentes are best developed in the lowest elevation band, from $5200 \mathrm{~m}$ to $5300 \mathrm{~m}$, where surface net all-wave radiation and temperature are largest, thus providing the energetic prerequisites for this phenomenon (Hofmann, 1964).

(iii) In the lower portion of the ice cap at 5 200-5 $300 \mathrm{~m}$, where penitentes are best developed, their orientation in terms of azimuth and elevation angle conforms to the insolation geometry around local noon, as discussed in the literature (Troll, 1942, p. 33-36; Hofmann, 1964; Kraus, 1966). The existence of a thick snow layer over the lower part of the ice cap this year is conducive to the maintenance of the penitentes. Where the ice below is reached, these features tend to collapse.

(iv) The aspect of large-scale topography may play a role for the cross-pattern of penitentes observed on the westward-facing slope at 5360 to $5380 \mathrm{~m}$.

(v) Ice crystals at the surface in this prolonged period without fresh snow-fall indicate that deposition prevails over ablation. An approximate balance between night-time deposition and day-time evaporation related to the delicate surface radiation budget has already been identified as a feature characteristic of the upper plateau of the Quelccaya (Hastenrath, 1978). During 1979 conditions seemed to have been particularly favorable for deposition.

(vi) Preferred shapes of ice crystals show a marked dependence on elevation: proceeding upward there is a change from surface-parallel plates to elaborate dendritic forms. Columns and needles approximately perpendicular to the surface are also encountered. In the study of cloud physics, a similar progression in crystal shape has been found as a function of temperature. For supersaturations beyond $15-20 \%$ with respect to ice, Mason (1975, p. 78-89) reports from his laboratory experiments the following characteristic forms: hexagonal plates for o to $-3{ }^{\circ} \mathrm{C}$; needles for -3 to $-5^{\circ} \mathrm{C}$; prisms for -5 to $-8^{\circ} \mathrm{C}$; plates for -8 to $-12^{\circ} \mathrm{C}$; dendrites for $-\mathrm{I} 2$ to $-\mathrm{I} 6^{\circ} \mathrm{C}$; and again plates below $-\mathrm{I}^{\circ} \mathrm{C}$. A more complex dependence of forms on both temperature and vapor-pressure conditions is indicated for smaller supersaturations. At night when crystal formation with preference takes place, temperatures between -8 and $-14^{\circ} \mathrm{C}$ may occur at various elevation bands of Quelccaya. From the aforementioned daily temperature variation, night-time supersaturations of $20 \%$ near the surface of the Quelccaya plateau are expected to be common. The sporadic occurrence of columns and needle-shaped crystals may be related to more complex vapor-pressure conditions. The spatial sequence of typical shapes described in Section 3 thus appears consistent with the upward decrease of temperature. Wind seems to play a role in the orientation of dendrites at the summit.

In conclusion, the large variety in the micro-morphology of the Quelccaya snow surface and the systematic altitude dependence of forms appear to be primarily controlled by the heat budget, with upward decrease of temperature and orientation of slope being important features in the origin of some features. The marked development of micro-forms encountered during the 1979 expedition was seemingly favored by the prolonged absence of fresh snow-fall, following a season of extremely abundant precipitation. Abundant snow-fall during most of the year, however, leads to a much different appearance of the surface at Quelccaya.

$M S$. received ro April 1980 


\section{REFERENGES}

Hastenrath, S. 1978. Heat-budget measurements on the Quelccaya ice cap, Peruvian Andes. Fournal of Glaciology, Vol. 20, No. 82, p. $85-97$.

Hofmann, G. 1964. Zur Rolle des Wärmehaushaltes bei der selektiven Ablation. Carinthia II (Klagenfurt), Sonderht. 24, p. 259-66.

Kraus, H. 1966. Freie und bedeckte Ablation. Ergebnisse des Forschungsunternehmens Nepal-Himalaya, Lief. 3, p. $203-36$.

Mason, B. J. 1975. Clouds, rain, and rainmaking. Second edition. Cambridge, Cambridge University Press.

Thompson, L. G., and others. 1979. Climatic ice core records from the tropical Quelccaya ice cap, by L. G. Thompson, S. Hastenrath, and B. Morales Arnao. Science, Vol. 203, No. 4386, p. I240-43.

Troll, C. 1942. Büsserschnee in den Hochgebirgen der Erde. Petermanns Geographische Mitteilungen. Ergänzungsht. 240. 